\section{Taxonomic Diversity of Rhizosphere Bacteria in Golf Course Putting Greens at Representative Sites in the Southeastern United States}

\author{
Monica L. Elliott ${ }^{3}$ \\ Department of Plant Pathology, University of Florida, Fort Lauderdale \\ Research and Education Center, 3205 College Avenue, Fort Lauderdale, \\ FL 33314
}

\section{J.A. McInroy \\ Department of Entomology and Plant Pathology, Auburn University, Auburn, AL 36849}

\author{
K. Xiong ${ }^{1}$, J.H. Kim² ${ }^{2}$ and H.D. Skipper \\ Department of Crop and Soil Environmental Science, Clemson University, \\ Clemson, SC 29634
}

\section{E.A. Guertal \\ Department of Agronomy and Soils, Auburn University, Auburn, AL 36849}

Additional index words. bacteria, bentgrass, bermudagrass, GC-FAME, golf course, rhizosphere

\begin{abstract}
Taxonomic diversity of bacteria associated with golf course putting greens is a topic that has not been widely explored. The purpose of this project was to isolate and identify culturable bacteria from the rhizosphere of creeping bentgrass (Agrostris palustris Huds.) at two sites (Alabama and North Carolina) and hybrid bermudagrass [Cynodon dactylon (L.) Pers. $\times$ C . transvaalensis Burtt-Davy] at two sites (Florida and South Carolina) for a minimum of 3 years with sampling initiated after the construction process. Randomly selected colonies were identified using gas chromatography for analysis of fatty acid methyl ester profiles. Over $\mathbf{9 0 0 0}$ isolates were successfully analyzed. When a similarity index of 0.300 or higher was used, the average number of unidentifiable isolates was $38.6 \%$. The two dominant genera in both bentgrass and bermudagrass rhizospheres were Bacillus and Pseudomonas with Bacillus dominant in bermudagrass and Pseudomonas dominant or equal to Bacillus in bentgrass. Other genera that comprised at least $1 \%$ of the isolates at all four sites were Clavibacter, Flavobacterium, and Microbacterium. Arthrobacter also comprised a significant portion of the bacterial isolates in the bentgrass rhizosphere, but not the bermudagrass rhizosphere. Overall, there were 40 genera common to all four sites. At the species level, there were five that comprised at least $1 \%$ of the isolates at each location: B. cereus, B. megaterium, $C$. michiganensis, $F$. johnsoniae, and $P$. putida. As has been reported for many grasses, we found considerable taxonomic diversity among the culturable bacterial populations from the rhizospheres of bentgrass and bermudagrass grown in sand-based putting greens.
\end{abstract}

Golf course putting greens are composed of a turfgrass monoculture. In the southeastern United States, bentgrass (Agrostis palustris Huds.) and hybrid bermudagrass [Cynodon dactylon (L.) Pers. $\times$ C. transvaalensis BurttDavy] are the dominant turfgrass species used on putting greens. Bermudagrass, a

Received for publication 27 Aug. 2007. Accepted for publication 11 Oct. 2007.

This research was supported, in part, by a grant from the U.S. Golf Association and by the Agricultural Experiment Stations of Alabama, Florida, and South Carolina.

${ }^{1}$ Current address: Nalco Co., Naperville, IL 60563. ${ }^{2}$ Current address: 1403 Chloe Drive, Lawrenceville, GA 30043

${ }^{3}$ To whom reprint requests should be addressed; e-mailmelliott@ufl.edu putting greens and conventional cropping systems is the "soil" composition of the root zone. In the past 30 years, the composition of most putting greens has evolved into artificially constructed soils built from a predetermined mixture of $80 \%$ to $90 \%$ sand and $10 \%$ to $20 \%$ organic matter. The organic matter is typically peat moss, reed sedge peat, or other well-degraded organic matter (USGA Green Section Staff, 1993). Percent clay content is kept to a minimum, which results in a reduced cation exchange capacity and poorer water retention (Bigelow et al., 2004).

In the southeastern United States, newly built putting greens are often fumigated with methyl bromide before being planted. This helps ensure destruction of weed seeds, parasitic nematodes, and common bermudagrass (C. dactylon). Although fumigation might produce a plant growth medium with significantly reduced microbial populations, previous research has shown that microbial populations rebound quickly after fumigation (Elliott and Des Jardin, 2001; Elliott et al., 2004). This is especially true for hybrid bermudagrass putting greens, because grass establishment requires the use of vegetative sprigs that would have been grown in "soil," either natural or artificially constructed (Elliott and Des Jardin, 2001). Furthermore, if sod is used for putting green establishment, microbial populations would be introduced with the "soil" associated with the sod. In addition, the nature of the root zone mix itself will change over time, because thatch, root, and shoot production will cause significant increases in organic matter (Carrow, 2003; Gaussoin et al., 2006).

Increasingly, microbial populations and microbial communities associated with turfgrasses are being examined in part because there is concern that turfgrass systems are not sustainable, especially on golf courses where intensive management (e.g., pesticide applications) is routine. The golf course industry uses numerous supplements that may include natural materials (e.g., seaweed extracts), plant hormones (e.g., auxins), and microbial inoculants (fungal and bacterial) (Elliott and Des Jardin, 1999; Mueller and Kussow, 2005). The latter are added because there is an assumption that either few microbes are present in the turfgrass system (as a result of the intensive management) or the "wrong" microbes are present. Altering the microbial community present from the "wrong" or "bad" microbes to "good" microbes is the purpose of adding natural materials. However, recent studies would indicate that turfgrass systems do have extensive microbial populations (e.g., Bigelow et al., 2002; Elliott et al., 2004; Feng et al., 2002; Mercier, 2006) and diverse microbial communities (e.g., Mueller and Kussow, 2005; Sigler et al., 2001; Yao et al., 2006).

Although some of these studies have examined microbial community diversity in general, taxonomic diversity within these communities has not been examined except in a broad sense based on semiselective 
media and techniques for particular bacterial groups. Thus, it is not known which culturable fluorescent pseudomonad species or which culturable bacilli species are present in the root zone. Although culturable bacteria may represent a small proportion of the total bacteria in the soil or rhizosphere (Alexander, 2005), knowledge of the culturable bacterial species and genera associated with turfgrass roots on golf courses would be useful, because this information might influence the selection of bacteria used for biological pest control or microbial inoculants (Cook et al., 1996; Lugtenberg and Dekkers, 1999; Nijhuis et al., 1993; Weller, 1988) and possibly explain successes and failures that have occurred. Although it is unclear whether introduced bacteria can influence bacterial populations currently present in the phyllosphere, thatch, rhizosphere soil, or bulk soil (Bankhead et al., 2004; Hodges et al., 1993; Lynch, 2002; Mercier, 2006; Mueller and Kussow, 2005; Siciliano and Germida, 1998; Sigler et al., 2001), it is still important to know which bacterial species or groups of species are expected to be present in a turfgrass system.

The purpose of this study was to examine taxonomic diversity of rhizosphere bacteria on bentgrass and bermudagrass grown in sand-based putting greens in the southeastern United States. The study described here was part of an overall project to examine various aspects of bacterial populations associated with putting greens (Elliott et al., 2003, 2004; Wang and Skipper, 2004). The bacterial isolates analyzed here were obtained while examining the flux in rhizosphere bacterial populations in golf course putting greens (Elliott et al., 2004).

\section{Materials and Methods}

Study sites. Rhizosphere samples from two different turfgrass species (bentgrass and hybrid bermudagrass) were obtained from four locations that have been described previously (Elliott et al., 2004). Briefly, the bentgrass putting greens were located at the Charlotte Country Club Golf Course, Charlotte, NC, and Auburn University, Auburn, AL. Putting greens were reconstructed (North Carolina, Summer 1996) or newly constructed (Alabama, Spring 1997) with a root zone mix composed of quartz sand and either Canadian sphagnum peat (North Carolina) or reed sedge peat (Alabama). Both locations were planted with the bentgrass cultivar 'Crenshaw', with the North Carolina site planted using seed and the Alabama site planted using washed sod that had been grown on plastic. The hybrid bermudagrass putting greens were located at the Cougar Point Golf Course, Kiawah Island, SC, and the University of Florida, Fort Lauderdale, FL. Putting greens were reconstructed (South Carolina, Summer 1996) or newly constructed (Florida, Spring 1997) with a root zone mix composed of quartz sand and Canadian sphagnum peat. Both locations were planted with the bermudagrass cultivar
'Tifdwarf' using vegetative sprigs. All four sites were fumigated with methyl bromide before planting the turfgrass. Putting greens located at university sites (Alabama and Florida) were miniature versions $(1.0 \times$ $0.5 \times 0.5 \mathrm{~m}$ in Alabama; $0.9 \times 0.9 \times 0.45 \mathrm{~m}$ in Florida) of those found on golf courses. All greens were managed in a manner typical for the region.

Sample collection and processing. Four putting greens from each location were sampled four times per year (approximately every 3 months) for a minimum of $3 \mathrm{y}$ in 1997 to 2000. Initiation date of sampling varied among sites but was initiated at each site when the putting greens were considered ready for golf play. Sample collection and isolation of bacteria have been described previously (Elliott et al., 2004). Briefly, samples were obtained using an ethanoldisinfected 1-cm-diameter soil probe to a depth of $10 \mathrm{~cm} ; 10$ cores were collected per putting green to constitute a sample. Green tissue was removed from each core with a sterile razor blade. All samples were kept on ice and stored at $4{ }^{\circ} \mathrm{C}$ until analyzed. For each sample, turfgrass roots were separated from the root zone mix. All root material and rhizosphere soil were placed in a sterile flask with diluent $\left(0.1 \% \quad \mathrm{Na}_{2} \mathrm{P}_{2} \mathrm{O}_{7}\right.$ with $1 \%$ glycerol) and immediately subjected to shaking for 30 minutes. Aliquots of dilutions were spread plated onto duplicate plates of selective and nonselective media (Elliott et al., 2004). For enumeration of total aerobic bacteria and selection of bacteria for identification with gas chromatography for analysis of fatty acid methyl ester profiles (GC-FAME), solidified 10\% tryptic soy broth (10\% TSBA), amended with $100 \mu \mathrm{g} \cdot \mathrm{mL}^{-1}$ cycloheximide to inhibit fungi, was used.

Alabama and Florida samples were processed at the University of Florida; South Carolina and North Carolina samples were processed at Clemson University. For each sampling date, 40 bacterial isolates per green sampled were randomly selected from the $10 \%$ TSBA for future identification. Isolates were selected from plates with $\approx 300$ colonyforming units or less. These isolates were streaked for purity on $10 \%$ TSBA and stored and shipped to Auburn University for analysis with GC-FAME. An estimated 10,000 bacterial isolates were selected for identification over the course of this study. Because only the standard aerobe libraries were used for identification (see subsequently), colonies that appeared to be members of the Streptomycetaceae were not selected for identification.

Gas chromatography for analysis of fatty acid methyl ester profiles. Analysis of the bacterial isolates was determined using the Sherlock ${ }^{\circledR}$ Microbial Identification System (MIDI, Newark, DE) at Auburn University or, as needed, at the Multiuser Laboratory at Clemson University. Isolates were transferred from storage and then cultured and processed according to the protocol for aerobic bacteria of environmental origin (Sasser,
2006). Fatty acid peak profiles were analyzed using the Sherlock Standard Aerobe Libraries (MIS version 4.0; Microbial ID, http:// www.midi-inc.com). According to literature provided by MIDI, strains with a similarity index (SI) of 0.500 or greater are considered a good match at the species level, whereas strains with a SI between 0.300 and 0.499 are considered a good match at the species level but indicate an atypical strain (Anonymous, 2005a). Because the bacterial species present in putting greens were largely unknown when this study was initiated, an SI of 0.300 or greater was used as the basis for identifying bacterial isolates.

\section{Results and Discussion}

A total of 9216 isolates were successfully analyzed using the Sherlock ${ }^{\circledR}$ Microbial Identification System. The predominant genera identified with GC-FAME when an SI of 0.300 or greater was used are shown in Table 1. These are the bacterial genera that comprised at least $1 \%$ of the total isolates for at least one site. There were five genera that comprised at least $1 \%$ of the isolates at all four sites: Bacillus, Clavibacter, Flavobacterium, Microbacterium, and Pseudomonas with Bacillus and Pseudomonas the dominant bacterial genera at each location. However, the percentage of isolates identified as Bacillus in the bermudagrass sites (Florida and South Carolina) was almost twice the number of isolates identified as Pseudomonas. At the bentgrass sites, Pseudomonas was either the dominant genus (North Carolina) or was equal to Bacillus (Alabama).

Two genera, Arthrobacter and Kocuria, comprised at least $1 \%$ of the isolates at the Alabama, North Carolina, and South Carolina sites, but not Florida, although they were identified at the Florida site. Arthrobacter comprised a significant portion of the bacterial isolates at the bentgrass sites $(9.1 \%$ at Alabama and $7.5 \%$ at North Carolina) with only Bacillus and Pseudomonas comprising a greater percentage of the isolates identified. Although Stenotrophomonas was identified from all four sites, it comprised at least $1 \%$ of the isolates only at the Florida and South Carolina bermudagrass sites. Some genera comprised at least $1 \%$ of the isolates analyzed at single sites only: Sphingomonas, Variovorax, and Xanthobacter in Alabama bentgrass; Xanthomonas in North Carolina bentgrass; Curtobacterium and Cytophaga in South Carolina bermudagrass; and Brevundimonas in Florida bermudagrass.

Although there is no comparable study on taxonomic diversity of bacteria associated with turfgrass rhizospheres, a GC-FAME identification study has been conducted on rhizosphere bacteria of wheat, a cool-season grass crop (Germida and Siciliano, 2001). In that study, conducted in a single year in Saskatchewan, Canada, the dominant genera identified were Pseudomonas, Arthrobacter, Bacillus, Curtobacter, Cytophaga, and Flavobacterium. In other single-season studies examining taxonomic diversity of 
rhizosphere bacteria, Pseudomonas and Bacillus were dominant genera identified in sugar beet (Lilley et al., 1996), cucumber (Mahaffee and Kloepper, 1997), and canola (Siciliano and Germida, 1999). Other dominant genera in these studies included Arthrobacter (sugar beet and canola), Flavobacterium (sugar beet), and Microbacterium (sugar beet). In multiple-year studies conducted in comparable climates to the study here, but with continuously cropped peanut and tobacco, the dominant genera identified were Arthrobacter in the tobacco rhizosphere (Kim et al., 2001/2002) and Burkholderia in the peanut rhizosphere (Gooden et al., 2004).

Overall, there were 50, 57, 64, and 64 bacterial genera identified in Alabama bentgrass, North Carolina bentgrass, Florida bermudagrass, and South Carolina bermudagrass, respectively (complete data set of genera at

Table 1. Genera isolated from bentgrass or bermudagrass putting greens as identified with GC-FAME with a similarity index $(\mathrm{SI})$ of 0.300 or greater.

\begin{tabular}{|c|c|c|c|c|}
\hline \multirow[b]{3}{*}{ Genera } & \multicolumn{4}{|c|}{ Percent of total isolates $^{\mathrm{z}}$} \\
\hline & \multicolumn{2}{|c|}{ Bentgrass } & \multicolumn{2}{|c|}{ Bermudagrass } \\
\hline & Alabama & North Carolina & South Carolina & $\overline{\text { Florida }}$ \\
\hline Acidovorax & $\mathrm{I}^{\mathrm{y}}$ & 1.7 & 1.8 & 3.0 \\
\hline Agrobacterium & 1.1 & I & 1.8 & 2.2 \\
\hline Arthrobacter & 9.1 & 7.5 & 1.1 & I \\
\hline Bacillus & 13.9 & 12.5 & 19.4 & 10.5 \\
\hline Brevundimonas & I & I & I & 1.1 \\
\hline Burkholderia & 1.2 & I & I & 1.5 \\
\hline Cellulomonas & I & 1.0 & I & 1.3 \\
\hline Chryseobacterium & I & 1.4 & 4.1 & I \\
\hline Clavibacter & 2.0 & 2.4 & 1.1 & 1.3 \\
\hline Comamonas & 3.8 & 1.8 & I & 2.0 \\
\hline Curtobacterium & I & I & 1.1 & I \\
\hline Cytophaga & $\mathrm{NM}^{\mathrm{x}}$ & NM & 1.1 & NM \\
\hline Flavobacterium & 1.5 & 1.9 & 1.4 & 1.7 \\
\hline Kocuria & 2.6 & 1.6 & 1.0 & I \\
\hline Microbacterium & 1.2 & 1.7 & 1.1 & 3.1 \\
\hline Paenibacillus & 1.4 & 1.3 & I & 1.6 \\
\hline Pseudomonas & 13.6 & 18.7 & 9.1 & 5.8 \\
\hline Ralstonia & NM & 1.2 & 1.0 & I \\
\hline Sphingomonas & 1.0 & I & I & I \\
\hline Stenotrophomonas & I & I & 1.7 & 1.2 \\
\hline Variovorax & 1.6 & I & I & I \\
\hline Xanthobacter & 1.4 & I & I & I \\
\hline Xanthomonas & I & 1.3 & I & I \\
\hline No match & 34.3 & 32.0 & 38.0 & 50.1 \\
\hline Other genera ${ }^{w}$ & 11.3 & 12.0 & 15.2 & 13.6 \\
\hline
\end{tabular}

${ }^{z}$ Total isolates analyzed is 1896 for Alabama, 2832 for North Carolina, 2617 for South Carolina, and 1871 for Florida.

${ }^{\mathrm{y}}$ Isolates were identified as this genus but composed less than $1 \%$ of the total isolates for that site. These isolates are included in the percentage of "other genera."

${ }^{\mathrm{x}} \mathrm{NM}=$ no isolate for that site had a match to this genus.

${ }^{\text {wE}}$ Each genus identified composed less than $1.0 \%$ of the total isolates analyzed using GC-FAME. There were other genera identified besides those listed for each site: 29 in Alabama, 35 in North Carolina, 41 in South Carolina, and 42 in Florida.

GC-FAME = gas chromatography for analysis of fatty acid methyl ester profiles.

Table 2. All genera, with similarity index of 0.300 or greater, common to golf course putting greens at all four locations (Alabama, Florida, North Carolina, and South Carolina).

\begin{tabular}{llll}
\hline Acidovorax & Cellulomonas & Hydrogenophaga & Pedobacter \\
Acinetobacter & Chryseobacterium & Janthinobacterium & Phyllobacterium \\
Agrobacterium & Clavibacter & Kocuria & Pseudomonas \\
Alcaligenes & Comamonas & Methylobacterium & Sphingobacterium \\
Arthrobacter & Corynebacterium & Microbacterium & Sphingomonas \\
Bacillus & Curtobacterium & Micrococcus & Stenotrophomonas \\
Bradyrhizobium & Enterobacter & Nesterenkonia & Tsukamurella \\
Brevibacterium & Enterococcus & Ochrobactrum & Variovorax \\
Brevundimonas & Exiguobacterium & Paenibacillus & Xanthobacter \\
Burkholderia & Flavobacterium & Pantoea & Xanthomonas \\
\hline
\end{tabular}

inant genera identified using GC-FAME, Bacillus and Pseudomonas, would have been enumerated with the semiselective medium and water bath technique. It is also consistent with the previously reported enumeration data that Bacillus is the dominant genus over Pseudomonas in the bermudagrass rhizosphere and that significantly greater numbers of fluorescent pseudomonads are found in the bentgrass rhizosphere than in the bermudagrass rhizosphere (Elliott et al., 2004).

The predominant species identified with GC-FAME when an SI of 0.300 or greater was used are shown in Table 3 . There were five species that comprised at least $1 \%$ of the isolates at all four sites: Bacillus cereus, B. megaterium, Clavibacter michiganensis, Flavobacterium johnsoniae, and Pseudomonas putida. Another three species-Agrobacterium radiobacter, $B$. pumilus, and $B$. thuringiensis - comprised at least $1 \%$ of the isolates at the Alabama, Florida, and South Carolina sites, but not the North Carolina site. A fourth species, Comamonas acidovorans, comprised at least $1 \%$ of the isolates at the North Carolina, Alabama, and Florida sites, but not the South Carolina site. One species was common at the $1 \%$ level only to the bermudagrass locations, Stenotrophomonas maltophilia. Four species were common at the $1 \%$ level only to the bentgrass locations, Arthrobacter ilicis, P. chlororaphis, $P$. fluorescens, and $P$. syringae.

There were some species that constituted at least $1 \%$ of the isolates at a single site location: Arthrobacter oxydans, A. protophormiae/ramosus, Kocuria kristinae, $K$. varians, Variovorax paradoxus, and Xanthobacter agilis in Alabama bentgrass; Arthrobacter aurescens, Paenibacillus polymyxa, and Ralstonia pickettii in North Carolina bentgrass; Chryseobacterium indologenes and $P$. mendocina in South Carolina bermudagrass; and Acidovorax facilis, Brevundimonas vesicularis, Microbacterium liquefaciens, and Paenibacillus macerans in Florida bermudagrass.

The number of unidentifiable isolates (SI less than 0.300 ) was $50.1 \%$ for Florida bermudagrass, $38.0 \%$ for South Carolina bermudagrass, $34.3 \%$ for Alabama bentgrass, and $32.0 \%$ for North Carolina bentgrass (Table 1). If the SI value is increased to 0.500 or greater, the number of unidentifiable isolates increases accordingly: $66.6 \%$ for Florida bermudagrass, $54.2 \%$ for South Carolina bermudagrass, $52.6 \%$ for Alabama bentgrass, and $51.1 \%$ for North Carolina bentgrass. These values fall within the range of $7.8 \%$ to $64 \%$ unidentifiable isolates obtained in other studies using GC-FAME for identification purposes (Axelrood et al., 2002; Germida and Siciliano, 2001; Gooden et al., 2004; Kim et al., 2001/2002; Lilley et al., 1996; Mahaffee and Kloepper, 1997; Poonguzhali et al., 2006; Siciliano and Germida, 1999). Three of these studies were conducted in field soils in Alabama and South Carolina, states where two of our study sites were located. In Alabama, $11.4 \%$ of the isolates from cucumbers could not be 
Table 3. Species isolated from bentgrass or bermudagrass putting greens as identified using GC-FAME with a similarity index (SI) of 0.300 or greater.

\begin{tabular}{|c|c|c|c|c|}
\hline \multirow[b]{3}{*}{ Genera } & \multicolumn{4}{|c|}{ Percent of total isolates ${ }^{z}$} \\
\hline & \multicolumn{2}{|c|}{ Bentgrass } & \multicolumn{2}{|c|}{ Bermudagrass } \\
\hline & Alabama & $\begin{array}{c}\text { North } \\
\text { Carolina }\end{array}$ & $\begin{array}{c}\text { South } \\
\text { Carolina }\end{array}$ & Florida \\
\hline$\overline{\text { Acidovorax facilis }}$ & $\mathrm{I}^{\mathrm{y}}$ & I & I & $\overline{1.2}$ \\
\hline Agrobacterium radiobacter & 1.1 & I & 1.8 & 2.0 \\
\hline Arthrobacter aurescens & I & 1.1 & I & $\mathrm{NM}^{\mathrm{x}}$ \\
\hline Arthrobacter ilicis & 2.0 & 2.5 & I & I \\
\hline $\begin{array}{l}\text { Arthrobacter oxydans } \\
\text { Arthrobacter }\end{array}$ & 2.2 & I & I & I \\
\hline protophormiae/ramosus & 2.1 & I & I & I \\
\hline Bacillus cereus & 4.8 & 9.2 & 9.3 & 3.6 \\
\hline Bacillus megaterium & 2.8 & 1.2 & 4.4 & 2.2 \\
\hline Bacillus pumilus & 3.1 & I & 2.0 & 1.6 \\
\hline Bacillus thuringiensis & 1.3 & I & 1.7 & 1.1 \\
\hline Brevundimonas vesicularis & I & I & I & 1.1 \\
\hline Chryseobacterium indologenes & I & I & 1.8 & I \\
\hline Clavibacter michiganensis & 2.0 & 2.4 & 1.1 & 1.3 \\
\hline Comamonas acidovorans & 3.4 & 1.7 & I & 1.7 \\
\hline Flavobacterium johnsoniae & 1.7 & 1.4 & 1.2 & 1.4 \\
\hline Kocuria kristinae & 1.3 & I & I & I \\
\hline Kocuria varians & 1.1 & I & I & I \\
\hline Microbacterium liquefaciens & I & I & I & 1.8 \\
\hline Paenibacillus macerans & I & I & I & 1.2 \\
\hline Paenibacillus polymyxa & I & 1.1 & I & I \\
\hline Pseudomonass chlororaphis & 2.7 & 1.9 & I & NM \\
\hline Pseudomonas fluorescens & 1.4 & 1.0 & I & I \\
\hline Pseudomonas putida & 6.8 & 8.9 & 3.3 & 1.8 \\
\hline Pseudomonas mendocina & I & I & 1.4 & I \\
\hline Pseudomonas syringae & 1.9 & 4.6 & I & I \\
\hline Ralstonia pickettii & NM & 1.0 & I & I \\
\hline Stenotrophomonas maltophilia & I & I & 1.7 & 1.2 \\
\hline Variovorax paradoxus & 1.6 & I & I & I \\
\hline Xanthobacter agilis & 1.1 & I & I & I \\
\hline No match & 34.3 & 32.0 & 38.0 & 50.1 \\
\hline Other species ${ }^{w}$ & 21.3 & 30.0 & 32.3 & 26.7 \\
\hline
\end{tabular}

zTotal isolates analyzed is 1896 for Alabama, 2832 for North Carolina, 2617 for South Carolina, and 1871 for Florida.

${ }^{\mathrm{y}}$ Isolates were identified as this species but composed less than $1 \%$ of the total isolates for that site. These isolates are included in the percentage of "other species."

${ }^{\mathrm{x}} \mathrm{NM}=$ no isolate for that site had a match to this species.

wEach species identified composed less than $1.0 \%$ of the total isolates analyzed using GC-FAME.

GC-FAME = gas chromatography for analysis of fatty acid methyl ester profiles.

identified (Mahaffee and Kloepper, 1997). In South Carolina, $35 \%$ and $41 \%$ of isolates from rotational peanut plots and continuous peanut plots, respectively, could not be identified (Gooden et al., 2004). Likewise, Kim et al. $(2001 / 2002)$ found up to $33 \%$ of isolates from continuous tobacco plots could not be identified. Thus, the number of unidentified isolates in the study here, obtained from an artificially constructed soil, would appear to be similar to the number from field soils in the same states using the same identification system.

The MIDI aerobic bacteria library includes fatty acid profiles for 695 environmental species with usually 20 or more strains representing each species or subspecies (Anonymous, 2005b; Sasser, 2006). Our results and those of others illustrate that a significant number of bacteria isolated from bulk or rhizosphere soils are not part of the bacterial collection that is the basis of the MIDI environmental species library. Any database is only as good as the data - in this case, fatty acid methyl ester profiles of bacterial isolates - accumulated within it. The unidentifiable isolates are not necessarily new species per se, but may simply be species not represented in the MIDI database. As indicated in the "Materials and Methods," isolates likely to represent the family Streptomycetaceae were not selected for identification purposes. The protocol and MIDI library for actinomycetes identification is different from that used for aerobes isolated from the environment (Anonymous, 2005b). Although it is still assumed that the vast majority of bacteria are not culturable, some laboratories are demonstrating that numerous species can be cultured with care (e.g., Joseph et al., 2003). This means many more genera and species than those identified in our study here are likely to be associated with bentgrass and bermudagrass roots in the southeastern United States.

The phyla represented by the genera either common to all four sites or dominant at multiple or single sites (i.e., constituting at least $1 \%$ of the isolates at one site) were Firmicutes (class 'Bacilli'), Proteobacteria (classes $\alpha$-, $\beta$-, and $\gamma$-Proteobacteria), Bacteroidetes (class Flavobacteria), and Actinobacteria (class Actinobacteria). This is the first study to survey for a portion of the culturable, aerobic bacterial genera and species common to golf course putting greens in the southeastern United States. It also demonstrates that there is considerable taxonomic diversity present in the rhizosphere of putting greens despite their intense management.

As part of the overall project, Wang and Skipper (2004) randomly selected 200 of the isolates from the North Carolina bentgrass and South Carolina bermudagrass locations to determine if any of the rhizosphere bacteria collected were denitrifiers. Of the 34 isolates determined to be denitrifiers and subsequently identified with GC-FAME and confirmed with 16S rDNA analysis, half are from the five dominant genera common to all four locations determined here [eight Pseudomonas, four Bacillus, two Clavibacter, two Microbacterium, and one Flavobacterium isolate(s)].

This illustrates that the actual functions of the species associated with turfgrass roots need further investigation. For example, Yao et al. (2006) recently showed, using Biolog ECO plates, that turfgrass microbial communities prefer carbohydrates, as opposed to microbial communities from the native pines located next to the golf course preferring carboxylic acids and amino acids. Yet, when products containing carbon sources were added to bentgrass putting greens, no changes were observed in the enzyme activities or substrate utilization of the microbial community (Mueller and Kussow, 2005). Observations such as these combined with the bacterial diversity observed in the study here illustrate that much more knowledge is needed before we can successfully and routinely manipulate microbial populations in the golf course turfgrass system to manage pests or simply improve plant health.

\section{Literature Cited}

Alexander, D.B. 2005. Bacteria and archaea, p. 101-139. In: Sylvia, D.M., J.J. Fuhrmann, P.G. Hartel, and D.A. Zuberer (eds.). Principles and applications of soil microbiology. 2nd ed. Pearson Prentice Hall, Upper Saddle River, NJ.

Anonymous. 2005a. Interpreting Sherlock reports. p. 4-1-4-9. In: MIS operating manual, Version 6.0, Sherlock ${ }^{\circledR}$ Microbial Identification System. MIDI, Inc., Newark, DE. 26 Jan. 2007. $<$ http://www.midi-inc.com/media/pdfs/MISMANUAL-6.0.pdf>.

Anonymous. 2005b. What is it? Sherlock ${ }^{\circledR}$ knows! MIDI, Inc., Newark, DE. 28 Nov. 2006 $<$ http://www.midi-inc.com/media/pdfs/BriefGC-Overview.pdf $>$.

Axelrood, P.E., M.L. Chow, C.S. Arnold, K. Lu, J.M. McDermott, and J. Davies. 2002. Cultivation-dependent characterization of bacterial diversity from British Columbia forest soils subjected to disturbance. Can. J. Microbiol. 48:643-654.

Bankhead, S.B., B.B. Landa, E. Lutton, D.M. Weller, and B.B.M. Gardener. 2004. Minimal changes in rhizobacterial population structure following root colonization by wild type and transgenic biocontrol strains. FEMS Microbiol. Ecol. 49:307-318.

Bigelow, C.A., D.C. Bowman, and D.K. Cassel. 2004. Physical properties of three sand size classes amended with inorganic materials or sphagnum peat moss for putting green rootzones. Crop Sci. 44:900-907. 
Bigelow, C.A., D.C. Bowman, and A.G. Wollum II. 2002. Characterization of soil microbial population dynamics in newly constructed sandbased rootzones. Crop Sci. 42:1611-1614.

Carrow, R.N. 2003. Surface organic matter in bentgrass greens. USGA Turfgrass Environ. Res. Online 2:1-10.

Cook, R.J., W.L. Brucart, J.R. Coulson, M.S. Goettel, R.A. Humer, R.D. Lumsden, J.V. Maddox, M.L. McManus, L. Moore, S.F. Meyer, P.C. Quimby, J.P. Stack, and J.L. Vaughn. 1996. Safety of microorganisms intended for pest and plant disease control: Framework for scientific evaluation. Biol. Control 7:333-351.

Elliott, M.L. and E.A. Des Jardin. 1999. Effect of organic nitrogen fertilizers on microbial populations associated with bermudagrass putting greens. Biol. Fertil. Soils 28:431-435.

Elliott, M.L. and E.A. Des Jardin. 2001. Fumigation effects on bacterial populations in new golf course bermudagrass putting greens. Soil Biol. Biochem. 33:1841-1849.

Elliott, M.L., E.A. Guertal, E.A. Des Jardin, and H.D. Skipper. 2003. Effect of nitrogen rate and root-zone mix on rhizosphere bacterial populations and root mass in creeping bentgrass putting greens. Biol. Fertil. Soils 37: 348-354.

Elliott, M.L., E.A. Guertal, and H.D. Skipper. 2004. Rhizosphere bacterial population flux in golf course putting greens in the southeastern United States. HortScience 39:1754-1758.

Feng, Y., D.M. Stoeckel, E. van Santen, and R.H. Walker. 2002. Effects of subsurface aeration and trinexapac-ethyl application on soil microbial communities in a creeping bentgrass putting green. Biol. Fertil. Soils 36:456-460.

Gaussoin, R., R. Shearman, L. Wit, T. McClellan, and J. Lewis. 2006. Soil physical and chemical characteristics of aging golf greens. USGA Turfgrass Environ. Res. Online 5:1-11.

Germida, J.J. and S.D. Siciliano. 2001. Taxonomic diversity of bacteria associated with the roots of modern, recent and ancient wheat cultivars. Biol. Fertil. Soils 33:410-415.
Gooden, D.T., H.D. Skipper, J.H. Kim, and K. Xiong. 2004. Diversity of root bacteria from peanut cropping systems. Peanut Sci. 31:86-91.

Hodges, C.F., D.A. Campbell, and N. Christians 1993. Evaluation of Streptomyces for biocontrol of Bipolaris sorokiniana and Sclerotinia homoeocarpa on the phylloplane of Poa pratensis. J. Phytopath. 139:103-109.

Joseph, S.J., P. Hugenholtz, P. Sangwan, C.A. Osborne, and P.H. Janssen. 2003. Laboratory cultivation of widespread and previously uncultured soil bacteria. Appl. Environ. Microbiol. 69:7210-7215

Kim, J.H., H.D. Skipper, D.T. Gooden, and K. Xiong. 2001/2002. Diversity of root bacteria from tobacco cropping systems. Tobacco Sci. 45:15-20.

Lilley, A.K., J.C. Fry, M.J. Bailey, and M.J. Day. 1996. Comparison of aerobic heterotrophic taxa isolated from four root domains of mature sugar beet (Beta vulgaris). FEMS Microbiol. Ecol. 21:231-242.

Lugtenberg, B.J.J. and L.C. Dekkers. 1999. What makes Pseudomonas bacteria rhizosphere competent? Environ. Microbiol. 1:9-13.

Lynch, J.M. 2002. Resilience of the rhizosphere to anthropogenic disturbance. Biodegradation 13:21-27.

Mahaffee, W.F. and J.W. Kloepper. 1997. Temporal changes in the bacterial communities of soil, rhizosphere, and endorhiza associated with field-grown cucumber (Cucumis sativus L.). Microbiol. Ecol. 34:210-223.

Mercier, J. 2006. Dynamics of foliage and thatch populations of introduced Pseudomonas fluorescens and Streptomyces sp. on a fairway turf. BioControl 51:323-337.

Mueller, S.R. and W.R. Kussow. 2005. Biostimulant influences on turfgrass microbial communities and creeping bentgrass putting green quality. HortScience 40:1904-1910.

Nijhuis, E.H., M.J. Maat, I.W.E. Zeegers, C. Waalwijk, and J.A. van Veen. 1993. Selection of bacteria suitable for introduction into the rhizosphere of grass. Soil Biol. Biochem. 25:885-895.
Poonguzhali, S., M. Madhaiyan, and T. Sa. 2006. Cultivation-dependent characterization of rhizobacterial communities from field grown Chinese cabbage Brassica campestris ssp pekinensis and screening of traits for potential plant growth promotion. Plant Soil 286: $167-180$.

Sasser, M. 2006. Bacterial identification by gas chromatographic analysis of fatty acids methyl esters (GC-FAME). Technical Note \#101. MIDI, Inc., Newark, DE.

Siciliano, S.D. and J.J. Germida. 1998. Biologic analysis and fatty acid methyl ester profiles indicate that pseudomonad inoculants that promote phytoremediation alter the rootassociated microbial community of Bromus biebersteinii. Soil Biol. Biochem. 30:17171723.

Siciliano, S.D. and J.J. Germida. 1999. Taxonomic diversity of bacteria associated with the roots of field-grown transgenic Brassica napus cv. Quest, compared to the non-transgenic $B$. napus cv. Excel and $B$. rapa cv. Parkland. FEMS Microbiol. Ecol. 29:263-272.

Sigler, W.V., C.H. Nakatsu, Z.J. Reicher, and R.F. Turco. 2001. Fate of the biological control agent Pseudomonas aureofaciens TX-1 after application to turfgrass. Appl. Environ. Microbiol. 67:3542-3548.

USGA Green Section Staff. 1993. USGA recommendations for a method of putting green construction. USGA Green Section Record Mar/Apr:1-3. USGA, NY.

Wang, G. and H.D. Skipper. 2004. Identification of denitrifying rhizobacteria from bentgrass and bermudagrass golf greens. J. Appl. Microbiol. 97:827-837.

Weller, D.M. 1988. Biological control of soilborne plant pathogens in the rhizosphere with bacteria. Annu. Rev. Phytopathol. 26: 379-407.

Yao, H., D. Bowman, and W. Shi. 2006. Soil microbial community structure and diversity in a turfgrass chronosequence: Land-use change versus turfgrass management. Appl. Soil Ecol. 34:209-218 